\title{
Selection and improvement of lactic acid bacteria used in meat and sausage fermentation
}

\author{
WP Hammes, C Hertel
}

Institute of Food Technology, Hohenheim University, Garbenstr 25, D-70599 Stuttgart, Germany

\begin{abstract}
Summary - Criteria for the selection of lactic acid bacteria (LAB) with application in meat fermentation are: i) suitability for propagation and preparation of starter cultures; and ii) safe performance in the fermenting substrate. The selection has to take in consideration the various, specific requirements of the fermentation process. In Europe these are usually best fulfilled by strains of Lactobacillus curvatus ( $L$ curvatus) and $L$ sake. Some strains of $L$ curvatus exhibit the potential to form tyramine and/or phenylethylamine and should not be used. Strains of $L$ sake are free of this potential. Suitable isolates should be competitive and suppress the growth of undesired organisms. The formation by the strains of bacteriocin (for example curvacin A) can increase their competitiveness. A final proof of the suitability of the isolate is obtained in practical tests. An improvement of $L A B$ in starter cultures can be achieved by either combining compatible strains to increase the overall metabolic activity above that level present in one single strain or by genetic modification. We have cloned and expressed in $L$ sake and $L$ curvatus the genes coding for catalase (katA) and lysostaphin (lys) by use of vectors derived from $L A B$ plasmids. Catalase activity is a technological important property not present in $L$ curvatus. Its expression was subjected to regulation in response to oxygen as it was observed in the gene donor $L$ sake. After removing repetitive sequences in lys, the transformed strains of $L$ sake and $L$ curvatus acquired the potential to kill staphylococci not only in fermenting sausages but also in mayonnaise-based salads.
\end{abstract}

lactic acid bacteria / fermented sausage / biogenic amine / catalase / lysostaphin

Résumé - Sélection et amélioration des bactéries lactiques utilisées dans la fermentation de la viande et des saucisses. Les critères de sélection des bactéries lactiques (LAB) pour leur utilisation dans des procédés de fermentation alimentaire sont : (i) leur aptitude à se développer et à entrer dans la préparation de levains lactiques, (ii) leur capacité reproductible à utiliser un substrat donné. La sélection de telles souches est un véritable défi puisqu'elle doit prendre en considération les besoins variés et spécifiques des procédés de fermentation. En Europe, ces besoins sont généralement les mieux couverts par des souches de Lactobacillus curvatus et $\mathrm{L}$ sake. Certaines souches de la première espèce peuvent produire de la tyramine et/ou de la phényléthylamine et par conséquent ne peuvent pas être utilisées. Les souches de $\mathrm{L}$ sake ne présentent pas cet inconvénient. Des souches naturelles appropriées devraient être compétitives et empêcheraient le développement de micro-organismes indésirables. La production par ces souches de bactériocines (par exemple curvacine A) peut augmenter leur compétitivité. La preuve finale que les souches naturelles sont adaptées n'est obtenue qu'au cours d'essais expérimentaux. Ceux-ci comprennent des analyses microbiologiques et chimiques (nitrate, nitrite, lactate, acétate) et une évaluation sensorielle (c'est-à-dire flaveur, couleur, 
texture) et la démonstration de la répétabilité des performances des souches. Une amélioration des bactéries lactiques dans les levains peut être obtenue soit en associant plusieurs souches compatibles de manière à ce que l'activité métabolique globale soit augmentée par rapport à ce qui est observé avec une seule souche, ou par modification génétique pour obtenir le même effet. Nous avons cloné et exprimé chez $\mathrm{L}$ sake et $\mathrm{L}$ curvatus plusieurs gènes en utilisant des vecteurs dérivés de plasmides de bactéries lactiques. Parmi les gènes clonés se trouvent ceux codant la catalase et la lysostaphine qui ont une importance pratique. L'expression de l'activité catalase est une propriété importante qui n'est pas présente chez $\mathrm{L}$ curvatus. L'expression du gène catalase est soumis à une régulation en fonction du niveau d'oxygène comme pour le gène provenant de la souche donneuse L sake. Après élimination des séquences répétées présentes dans le gène codant la lysostaphine, les souches de L sake et $\mathrm{L}$ curvatus expriment une activité staphylolytique dans les saucisses et dans les salades contenant de la mayonnaise.

\section{bactérie lactique / saucisse / amine biogène / catalase / lysostaphine}

\section{INTRODUCTION}

Fermented sausages are unique within the group of fermented foods as they possess the following characteristics: i) they require high priced raw materials which make up, on average, $75 \%$ of the price of the endproduct; ii) they differ widely in their sensory and physical appearance, eg, more than 300 types are consumed in Germany; iii) they are produced without any germreducing measures applied to the raw materials; and therefore iv) the raw materials may contain spoilage organisms and/or food pathogens which have to be reduced during the fermentation process.

To obtain the various types and qualities of sausages, different factors play an important role which include, for example, the choice of raw materials, the formula, the technology of meat processing and fermentation, the diameter and nature of the casings, storage condition, and age at consumption. Microorganisms involved in the fermentation process have to be effective within these technological boundaries. Their growth and metabolic activity is influenced by the known ecological factors which generally are the decisive criteria for all microorganisms (Hammes, 1991).

The specific conditions prevailing in the fermented sausages lead to a selective growth of an adapted flora which usually consists of lactic acid bacteria ( $L A B)$ and micrococci. In the initial fermentation phase, when $\mathrm{pH}$ and redox potential are still high, several other groups of organisms may multiply, among which are of importance enterobacteria and other organisms of potentially hygienic concern or exhibiting a potential to initiate malfermentation or spoilage.

\section{STARTER CULTURES IN MEAT FERMENTATION TECHNOLOGY}

To shorten the critical initial fermentation phase and to control the fermentation process, starter cultures were introduced in meat fermentation technology which are now widely applied. For the production of the various types of sausages, yeasts, moulds and bacteria in various combinations are applied (Hammes and Knauf, 1994). Within the group of fermenting bacteria LAB are of greatest importance, and the following species are used in meat production: Lactobacillus plantarum, $L$ sake, $L$ curvatus, Pediococcus pentosaceus, and $P$ acidilactici. LAB are involved in the processing of all types of fermented sausages and contribute to all aims of the fermentation process (Hammes et al, 1990). LAB form acids leading to a decrease of the $\mathrm{pH}$ of the sausage mixture during fermentation. This 
basic activity exerts numerous important changes in the substrate, eg, acid taste, preservation, hygienic stability, development of texture by coagulation of the proteins, and support of the reddening reaction via formation of nitrosomyoglobin. Finally, $L A B$ have an strong impact on the flavour of the sausages; it is remarkable that a great number of types of sausages require the additional contributions of further starter organisms. Their main achievements are, for example, reduction of nitrate and nitrite which are employed as curing aids, destruction of peroxides which may be formed by fortuitous $L A B$ and lead to discoloration and rancidity, and formation of flavour. In combinations of $\angle A B$ and starter organisms belonging to the other groups of microorganisms, it is important to exclude any antagonistic interferences among the various organisms.

To obtain strains of LAB which are most suitable as starter organisms, a careful screening is necessary which includes the study of the physiological, biochemical and for practical application important properties of the potential candidates. It is important to know their physiological potential with regard to fermentable substrates, product formation, regulation of the metabolism and stable maintenance of the necessary properties. Usually, practical tests will be the best proof for the suitability of a given strain. However, in technical meat production many process variations exist (see above) whose possible effects on the starter performance can be evaluated on the basis of extensive physiological data. Finally, for economical and practical reasons, the strains should be easy to grow and suitable for turning them into dry, storable starter preparations.

In more recent studies two aspects have attracted attention as it became evident that $L A B$ may possess unexpected properties. Food fermenting $L A B$ are considered not to be toxigenic or pathogenic (Hammes et al,
1992). There is, however, a potential to form biogenic amines in strains of certain species which might not be the appropriate candidates for use in starter cultures. To evaluate this potential in meat lactobacilli (Straub et al, 1995), we screened a great number of defined strains. As shown in table I, only strains of $L$ curvatus formed these amines in various combinations. There were, however, also strains without any potential for amine formation. To prevent the formation of biogenic amines in the fermenting sausages, it is necessary that the starter organisms do not only not form the amines but are also competitive and suppress the growth of the fortuitous competitors which otherwise might abolish the protective effect of the starter.

It is remarkable that $L A B$ have a potential to produce numerous antimicrobial compounds (Hammes and Tichazek, 1994) among which bacteriocins $(B C)$ have attracted scientific attention. Especially isolates from meat belonging to the species $L$ curvatus or $L$ sake contain relatively frequent BC-forming strains. Several compounds were chemically characterised and the genetic background of their formation has been elucidated (Tichaczek et al, 1992, 1993, 1994). It appears promising to make use of this potential in meat fermentations, as the compounds have an in vitro activity against microorganisms of hygienic concern or with a potential to cause spoilage or malfermentation. Ideally a producer strain suitable as starter organism should exhibit the following properties during the fermentation process:

- $B C$ formation during the fermentation stage;

- stability of the $B C$ in the fermentation substrate;

- no inactivation of the BC effect by food compounds;

- no interference of the BC with other useful starter organisms (eg, Staphylococcus carnosus and Micrococcus varians); 
Table I. The potential of meat lactic acid bacteria to form biogenic amines (adapted from Straub et al, 1995).

Bactéries lactiques de la viande pouvant former des amines biogènes (adapté de Straub et al, 1995).

\begin{tabular}{|c|c|c|}
\hline Species & No of strains & $\begin{array}{l}\text { No of positive strains } \\
\text { compound }^{*}(\% \text { turno }\end{array}$ \\
\hline L curvatus & 35 & $\begin{array}{c}\text { 10:TYA }(1.9-76.1) \\
\text { 10:TYA }(19.4-61.5) \\
\text { PHA }(1.7-6.9) \\
\text { 2:PUT }(33.9-42.7) \\
\text { CAD }(5.8-9.5) \\
\text { TYA }(35.8-66.1) \\
\text { 7: PUT }(23.2-92.2) \\
\text { CAD }(1.5-11.0) \\
\text { TYA }(8.5-52.4) \\
\text { PHA }(1.0-21.0)\end{array}$ \\
\hline
\end{tabular}

$\begin{array}{lll}\text { L pentosus } & 12 & 0 \\ \text { L plantarum } & 16 & 0 \\ \text { L rhamnosus } & 1 & 0 \\ \text { L sake } & 24 & 0 \\ \text { Pacidilactici } & 4 & 0 \\ \text { P pentosus } & 4 & 0\end{array}$

PUT, putrescine; CAD, cadaverine; HIA, histamine; TYA, tyramine; PHA, 2-phenylethylamine. The range of the turnover of the precursor amino acid is presented in parentheses.

Le niveau de renouvellement de l'acide aminé précurseur est indiqué entre parenthèses.

- inhibition of undesired organisms (eg, undesired competitive, fortuitous lactic acid bacteria, Staphylococcus aureus, Listeria monocytogenes).

In our group (Tichaczek et al, 1992) we have isolated and characterized two $B C$ forming strains belonging to the species $L$ curvatus and $L$ sake, respectively. Using the $L$ curvatus strain producing curvacin $A$ (Vogel et al, 1993), we have performed practical studies to make use of the isolates as starter and protective cultures, respectively. By comparison with an isogenic $\mathrm{Bac}^{-}$strain, it could be shown that the $\mathrm{BC}$ formation endows the starter with an competitive advantage. In sausages produced with the $\mathrm{Bac}^{+}$strain, the growth of otherwise highly competitive $L$ curvatus strains was suppressed. Thus, a clean fermentation process was achieved in which the $\mathrm{Bac}^{+}$strain was virtually the only $L A B$ detectable. As curvacin $A$ does not affect the growth of the desired co-starters belonging to the species Staphylococcus carnosus, and the sensory properties of the resulting sausages were excellent, the use of $\mathrm{BC}$ forming strains as starters is promising. On the other hand, antilisterial effects of the $\mathrm{BC}$ forming strains 
were rather poor under practical conditions in spite of a strong antilisterial effect in vitro (unpublished results).

\section{GENETIC MODIFICATION OF MEAT LAB}

To further improve starter cultures for meat fermentations, two approaches appear to be promising. First, multiple strain cultures can be applied in which the various starter strains achieve the desired effects in combination. Second, the desired properties are introduced into one or few single strains by means of genetical engineering. The latter way is hampered by a poor consumer acceptance of gentechnology, but offers the advantage that the spectrum of new properties can be increased beyond that found in potential meat organisms. Aims that might relatively easily be achieved by genetical engineering of meat $L A B$ are compiled in table II.

In studies performed in our laboratory, we aimed to apply genetical engineering to meat lactobacilli and to construct strains with specific activity against the food pathogen Staphylococcus aureus. Appropriate strains might acquire the potential to kill the target organism not only when used as starter cultures in fermenting sausages but also as protective cultures in other foods in which the growth of $S$ aureus might become a hazard. It was our aim to construct competitive strains of $L$ curvatus (LC) and $L$ sake (Ls) with high competitiveness in fermenting meat which should express staphylolytic activities (Hertel et al, 1995).

We selected as hosts Lc LTH1432 and Ls LTH673, as their practical suitability was well studied. The lysostaphin gene was attained on plasmid pUls23 (Heinrich et al, 1987). The gene was then introduced as HindIII fragment in Vector pJK356 (Klein et al, 1993). This vector was constructed from a $4.5 \mathrm{~kb}$ plasmid harboured in the meat starter LC LTH683. The resulting plasmid pLS100 was transferred to Bacillus subtilis 1012. Within the clones expressing the staphylolytic activities, one clone was detected containing a truncated insert. The plasmid contained therein was designated pLS100 and further investigated. It was observed that a spontaneous deletion had taken place within lys. In several sets of electroporation experiments it was observed that $L$ curvatus strains expressing lys could easily be obtained with pLS100 but never

Table II. Possible aims of genetic modification of meat lactic acid bacteria.

Objectifs possibles des modifications génétiques des bactéries lactiques de la viande.

Genetic manipulation

Improved food hygiene

Improvement of cultivation of starter organisms and their stability

Improved technological suitability

Improved flavour
Introducing genes coding for formation of bacteriocins or lytic activities

Introducing genes coding for phage resistance

Introducing the genes coding for catalase or bacteriocin production or reduction of nitrate and nitrite

Introducing or changing the genes coding for lipases and proteases 
with pLS101. pLS100 was also readily introduced and lys was expressed in L sake. Some clones were also obtained with pLS101 in which, however, lys was deleted from the plasmid after propagation for a few generations. These findings are consistent with the assumption that plasmids with the complete sequence of lys are structurally unstable in $L$ curvatus and $L$ sake.

The spontaneous deletion of lys located on pLS100 was analysed by restriction analysis. It was found that the deletion had taken place in the region coding for the prosequence of the lysostaphin precursor protein. In figure $1 \mathrm{a}$ and $\mathrm{b}$ the lysostaphin gene and preprolysostaphin are schematically depicted. As indicated, the deletion in pLS100 consisted of 12 repetitive DNA sequences within the prosequence. Based on the observation that the removal of repetitive sequences within lys improves the stable expression of the staphylolytic activity, we constructed further deleted genes with the aid of Pvull which specifically cuts between each of the sequences. From shortened genes two new plasmids were constructed (see fig 1a) designated pLS200 and pLS201. As observed with pLS100, with these plasmids it was possible to obtain clones of $L$ sake and $L$ curvatus that stably expressed the staphylolytic activity for over 20 generations.

The activity of the various clones was compared by measuring the reduction of the optical density of a suspension of heat inactivated staphylococcal cells. As shown in table III, highest activities were expressed when nine or ten repeats were deleted and, furthermore, the activity was stronger with cultures of $L$ sake than with $L$ curvatus.

The staphylolytic proteins were isolated from cultures of $L$ curvatus and subjected to gel electrophoresis. As shown in figure 2 , a family of proteins could be identified by staining with Coomassie blue as well as by visualizing the activity as halos in the staphylococcal top layer suspension. By deter- mining the $\mathrm{N}$-terminal sequences of the proteins it was found that the various proteins consisted of multiple forms of prolysostaphin of various length, in addition to the mature enzyme. Thus, in $L$ curvatus and $L$ sake lysostaphin was synthesized basically as in $S$ simulans, since corresponding forms were also found in this native producer of lysostaphin (Neumann et al, 1993).

We have used $L$ curvatus pLS200 and pLS100 in pilot experiments to evaluate a staphylolytic potential when applying the strains as starter or protective cultures. It was observed (Cavadini et al, 1994) that the organisms effectively killed staphylococci growing in the outer parts of fermenting sausages where oxygen has access and permits multiplication of the food pathogen.

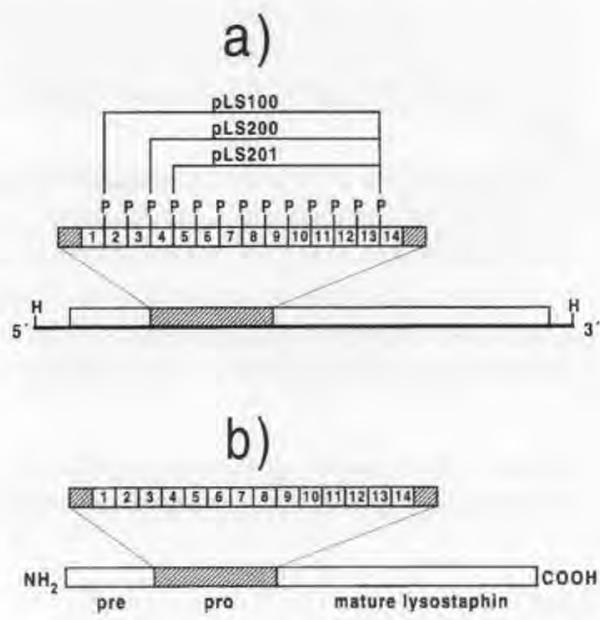

Fig 1. Scheme of the Hindlll fragment of pUls23 (Heinrich et al, 1987) carrying the lysostaphin gene (a) and the preprolysostaphin polypeptide (b). The deleted repetitive sequences of the lys genes located on plasmids pLS100, pLS200, and

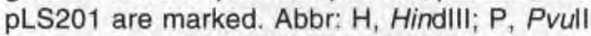
(adapted from Cavadini et al, 1995).

Schéma du fragment Hindlll de pUls23 (Heinrich et al, 1987) portant le gène codant la lysostaphine (a) et du polypeptide preprolysostaphine (b). Les séquences répétitives délétées des gènes lys situés sur les plasmides pLS100,pLS200 et pLS201 sont marquées. $H$, Hind III, P. Pvull (adapté de Cavadini et al, 1995). 
Table III. Lysostaphin activities of the Lactobacillus transformants (Cavadini et al, 1995). Activités de la lysostaphine des lactobacilles transformants (Cavadini et al, 1995)

Strain

Plasmid

pLS100

pLS200

pLS201

L curvatus LTH1432

L curvatus LTH 1432

L sake LTH673
Number of deleted repetitive sequences
$\%$ Reduction in optical

density $\times$ min $^{-1}$
kDa A

B

66.2 -

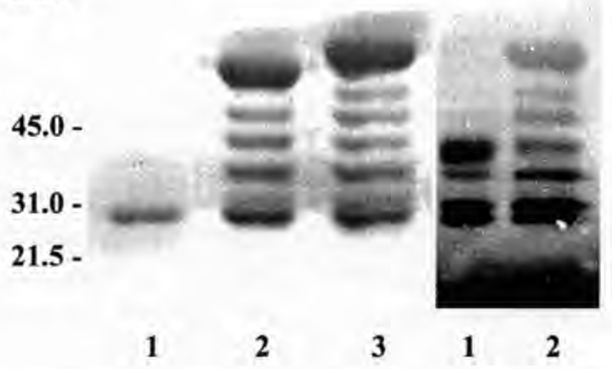

Fig 2. SDS-polyacrylamide gel electrophoresis of lysostaphin secreted by lactobacilli transformants. A. Protein staining with Coomassie brilliant blue; lane 1, control (lysostaphin from Sigma); lane 2, L curvatus (pLS200); lane $3, L$ curvatus (pLS201). B. Detection of halos produced by the active enzyme. The gel contained suspended staphylococcal cells as substrate. Bacteriolytic activities appear as dark zones in a light background; lane 1, L curvatus (pLS100); lane 2, L curvatus (pLS201) (with permission, Cavadini et al, 1995).

Électrophorèse sur gel de polyacrylamide-SDS de la lysostaphine sécrétée par les lactobacilles transformants. A. Protéine colorée au bleu de Coomassie ; 1, contrôle (lysostaphine Sigma) ; 2 , L curvatus ( $p L S 200) ; 3$, L curvatus ( $p$ LS201). B. Détection des halos produits par l'enzyme active. Le gel contient une suspension de cellules de staphylocoques qui sert de substrat. Les activités bactériolytiques apparaissent sous forme de zones foncées sur fond clair. 1, L curvatus ( $p L S 100) ; 2$, L curvatus ( $p L S 201$ ) (Cavadini et al, 1995, avec permission).
Furthermore in mayonnaise-based meat salads an even stronger staphylolytic and therefore protective effect was detected.

As a second approach to improve a meat starter LAB, we selected a trait of technological importance in sausage fermentations. When oxygen has access to the organisms, eg, in the outer part of the sausages, the organisms form hydrogen peroxide. This highly oxidative compound may cause deleterious effects in the sausages such as discoloration or rancidity. To prevent such defects, it is necessary to employ starter organisms that exhibit catalase activity. At present staphylococci and micrococci are used that fulfil this requirement. In addition, such $L A B$ strains are in use that can split hydrogen peroxide. As observed by Engesser and Hammes (1994), strains can be detected among meat $\mathrm{LAB}$ which exhibit either the activity of pseudocatalase or of a true catalase. In the latter case, it is necessary for obtaining active enzymes that heme is provided in the medium. As fermenting meat is rich in porphorynoids catalase functions well in these organisms under practical conditions.

From table IV it can be derived that strains of $L$ curvatus do not possess any of the catalases and, therefore, strongly produce $\mathrm{H}_{2} \mathrm{O}_{2}$. It was our aim to clone and express the catalase gene from $L$ sake LTH677 as it was well characterized (Knauf et al, 1992) and the biochemical and phys- 
iological properties of the enzyme were also known. We were aware that the successful expression of the gene in L curvatus might be impossible, as it is known that in $L$ sake the enzyme activity is subjected to regulation. It is repressed under anaerobic conditions and in the presence of high ( $>1 \%$ ) concentrations of glucose. Thus, the success of the cloning experiments depended on the function of the regulatory mechanisms in L curvatus.

We used again as vector pJK356 and constructed pLSC 300 harbouring katA from $L$ sake. As host served L curvatus LTH1432 and we obtained clones that expressed catalase activity. The physiological investigation of the clones revealed that the enzyme expression of cultures of the construct $L$ curvatus (pLSC300) LTH4002 was basically as in $L$ sake. As shown in figure 3 , catalase activity was induced by aeration of the culture. As the addition of erythromycin to the culture did not abolish this effect and the induction was accompanied by an increase in the amount of the specific mRNA (see fig 4), the induction has taken place on the level of transcription. A further inductory effect was also observed for glucose at concentrations above $1 \%$.

With regard to the inductory effect of oxygen, it is remarkable that the catalase gene of $L$ sake contains a putative regulator binding site with structural and sequential similarity to the consensus sequence of FNR. The existence of a FNR like protein (FLP) was recently reported for $L$ casei (Invine and Guest, 1993). This observation is consistent with the assumption that the corresponding elements of the sensor and regulator mechanism operate in L curvatus.

\section{CONCLUSIONS}

To match the requirements of sausage fermentation under industrial conditions suitable starters are advantageously employed. These can be further improved by selecting new competitive strains that take into account more recent reports on the metabolic and genetic potential of LAB. By

Table IV. Potential of meat $L A B$ to produce $\mathrm{H}_{2} \mathrm{O}_{2}$ or to exhibit catalase activity (Hammes and Knauf, 1994).

Bactéries lactiques de la viande pouvant produire $\mathrm{H}_{2} \mathrm{O}_{2}$ ou manifester une activité catalase (Hammes et Knauf, 1994).

$*$ formation
of $\mathrm{H}_{2} \mathrm{O}_{2}$

L plantarum

Lsake

L curvatus

P pentosaceus

$P$ acidilactici

\pm
+
+
-
+

+ , property is present; - , property is absent; \pm , strain dependent property.

+, propriété présente ; -, propriété absente ; \pm , propriété souche-dépendante.
Presence of the activities of pseudocatalase true catalase 
application of gentechnology it is possible to improve the most competitive lactobacilli ( $L$ sake and $L$ curvatus). This was shown

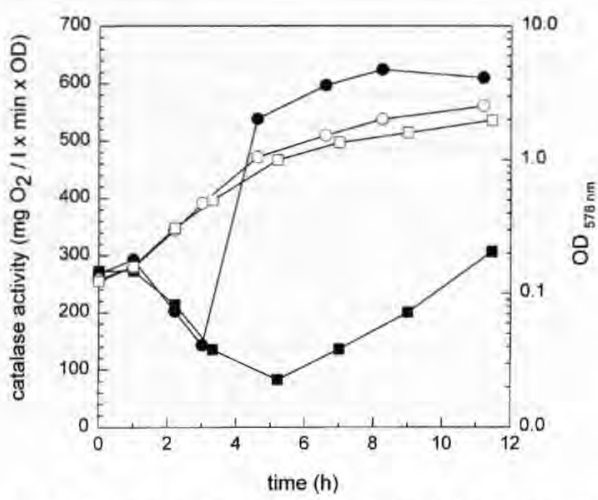

Fig 3. Induction of catalase activity by aeration. $L$ curvatus LTH4002 (pLS300) was cultured anaerobically. After $3 \mathrm{~h}$, one culture (-) was aerated and the control ( $\mathbf{a})$ remained anaerobic. OD, open symbols; catalase activity, solid symbols. Induction de l'activité catalase par aérobiose. L curvatus LTH4002 (pLS300) était cultivé en anaérobiose. Après $3 \mathrm{~h}$, une culture (- était

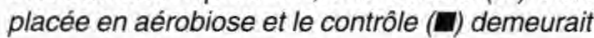
en anaérobiose. Symboles ouverts : DO; symboles fermés : activité catalase.

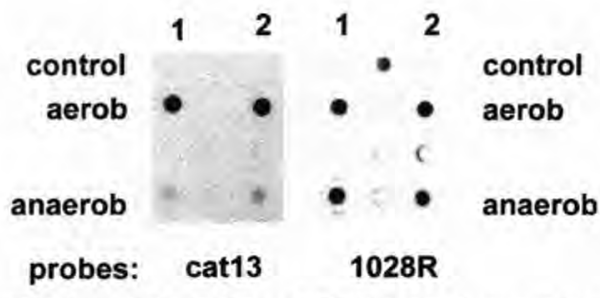

Fig 4. Hybridization of RNA from $L$ curvatus LTH4002 (pLS300) with probes specific for katA (kat13) and universal 23S rRNA gene (1023R). In two sets of experiments ( 1 and 2 ) the cells were grown either aerobically or anaerobically. $L$ curvatus $\mathrm{LTH}_{1432}$ (Kat-) was used as control.

Hybridation de I'ARN de L curvatus LTH4002 ( $p L S 300$ ) avec des sondes spécifiques pour katA (Kat13) et pour le gène universel ARNr 23S (1023R). Dans deux séries d'essais (1 et 2), les cellules étaient cultivées soit en aérobiose, soit en anaérobiose. L curvatus LTH1432 (kat) était utilisé comme contrôle. with the transfer of the genes coding for lysostaphin and catalase, respectively. The resulting strains can improve food hygiene and sensory food quality.

\section{ACKNOWLEDGMENTS}

This work was supported by grants from the Arbeitsgemeinschaft industrieller Forschungsvereinigung (AIF no 9559), the Bundesministerium für Forschung und Technologie (0319280B), the Fraunhofer-Gesellschaft (11-104035), and the European Community (BIOT-CT91-0263).

\section{REFERENCES}

Cavadini C, Hertel C, Hammes WP (1994) Expression of lysostaphin in Lactobacillus curvatus to control food poisoning by Staphylococcus aureus. Conference on Lactic Acid Bacteria. Which strains? For which markets? Held in Caen. Adria-Normandie (ed), Villers-Bocage, abstract 41

Cavadini C, Hertel C, Hammes WP (1996) Stable expression of the lysostaphin gene in meat lactobacilli by introducing deletions within the prosequence. Syst Appl Microbiol, in press

Engesser DM, Hammes WP (1994) Non-heme catalase activity of lactic acid bacteria. Syst Appl Microbiol $17,11-19$

Hammes WP (1991) Fermentation of non-dairy food. Food Biotechnol 5, 293-303

Hammes WP, Knauf HJ (1994) Starters in the processing of meat products. Meat Sci $36,155-168$

Hammes WP. Tichaczek PS (1994) The potential of lactic acid bacteria for the production of safe and wholesome food. Z Lebensm Unters Forsch 198, 193-201

Hammes WP, Bantleon A, Min S (1990) Lactic acid bacteria in meat fermentation. FEMS Microbiol Rev 87 , 165-173

Hammes WP, Weis N, Holzapfel W (1992) The genera Lactobacillus and Carnobacterium. In: The Prokaryotes, 2nd edn (Balows A, Trüper HG, Dworkin M, Harder W, Schleifer KH, eds) Springer Verlag, New York

Heinrich P, Rosenstein R, Böhmer M, Sonner P, Götz F (1987) The molecular organization of the lysostaphin gene and its sequences repeated in tandem. Mol Gen Genet 209, 563-569

Hertel C, Cavadini C, Hammes WP (1995) Deletiertes Lysostaphingen von Staphylococcus simulans, German patent application P 4425645.0 
Irvine AS, Guest JR (1993) Lactobacillus casei contains a member of the CRP-FNR family. Nucleic Acids Res 21, 753

Klein JR, Ulrich C, Plapp R (1993) Characterization and sequence analysis of a small cryptic plasmid from Lactobacillus curvatus LTH683 and its use for construction of new Lactobacillus cloning vectors. Plasmid $30,14-29$

Knauf HJ, Vogel RF, Hammes WP (1992) Cloning, sequence and phenotypic expression of katA, which encodes the catalase of Lactobacillus sake LTH677. Appl Environ Microbiol 58, 832-839

Neumann VC, Heath HE, LeBlanc PA, Sloan GL (1993) Extracellular proteolytic activation of bacteriolytic peptidoglycan hydrolases of Staphylococcus simulans biovar staphylolyticus. FEMS Microbiol Lett 110, 205-212

Straub BW, Kicherer M, Schilcher SM, Hammes WP (1995) The formation of biogenic amines by fer- mentation organisms. Z Lebens Unters Forsch 201, 79-82

Tichaczek PS, Nissen-Meyer J, Nes I, Vogel RF, Hammes WP (1992) Characterization of the bacteriocins curvacin A from Lactobacillus curvatus LTH1174 and sakacin P from Lactobacillus sake LTH673. Syst Appl Microbiol 15, 460-468

Tichaczek PS, Vogel RF, Hammes WP (1993) Cloning and sequencing of cur $A$ encoding curvacin $\mathrm{A}$, the bacteriocin produced by Lactobacillus curvatus LTH1174. Arch Microbiol 160, 279-283

Tichaczek PS, Vogel RF, Hammes WP (1994) Cloning and sequencing of sakP encoding sakacin $P$, the bacteriocin produced by Lactobacillus sake LTH673. Microbiology 140, 361-367

Vogel RF, Pohle S, Tichaczek PS, Hammes WP (1993) The competitive advantage of Lactobacillus curvatus LTH1174 in sausage fermentations is caused by formation of curvacin A. Syst Appl Microbiol 16, 457-462 